\title{
Aetio-Prevalence Study on Bovine Sub Clinical Mastitis in Lactating Jersey Cross-Bred Cows
}

\author{
Syed Ishfaq Ahmad Qadri*, Muzaffar Shaheen, Shafayat ullah Baig, Hamidullah Malik, \\ Zaffar Iqbal Bhat, Imtiyaz Ahmad Bhat, Pervaiz Ahmad Dar, Rather Waseem Yousuf, \\ Raja Mohammed Iqbal, Adil Majid Bhat, Abrar ul Haq, Ifat Ashraf, Oveas Rafiq Parray, \\ Fayaz Ahmad Shaikh, Bilal Ahmad Mir and Tasaduq Khaliq \\ Division of Medicine, Faculty of Veterinary Science, SKUAST-K, Srinagar-190006, India \\ *Corresponding author
}

\begin{tabular}{|c|c|}
\hline & $\mathbf{A} \mathbf{B} \mathbf{S} \mathbf{T} \mathbf{A} \mathbf{C}$ \\
\hline & \multirow{6}{*}{$\begin{array}{l}\text { An investigation was conducted on subclinical mastitis at State University dairy farm, } \\
\text { Mansbal in which } 100 \text { lactating Jersey cross bred cows were taken in to study. The animals } \\
\text { showing clinical signs of mastitis were excluded from the study. Californian Mastitis test } \\
\text { (CMT) and somatic cell count (SCC) were used for preliminary screening of animals for } \\
\text { subclinical mastitis. Prevalence of subclinical mastitis on the basis of CMT was } 52 \% \text { while } \\
\text { as the prevalence on the basis of SCC was } 49 \% \text {. On culture examination } 45 \% \text { was per cent } \\
\text { prevalence of subclinical mastitis. The major mastitides isolated were Staphylococci, } \\
\text { Streptococci and E.coli whereas the minor pathogens incriminated in mastitis were } \\
\text { Diplococcus, Corynebacterium, Pseudomonas, Micrococcus and Bacillus species. Out of } \\
\text { which staphylococcus spp. was } 42.2 \% \text {, Streptococcus spp. was } 11.1 \% \text {, Escherichia coli } \\
\text { was } 6.6 \% \text {, Diplococcus spp. } 2.2 \% \text {, Corynebacteriumspp. } 2.2 \% \text {, Pseudomonassp. } 2.2 \% \text {, } \\
\text { mixed Staphylococcus and Streptococcus } 22.2 \% \text {, Gram negative but not Escherichia coli, } \\
4.4 \% \text { Micrococcus } 2.22 \% \text { and Bacillus species was } 4.44 \% \text {. Out of staphylococcal, } 73.68 \% \\
\text { were coagulase negative while as coagulase positive were } 26.31 \% . \text { Out of streptococci, } \\
60 \% \text { were alpha haemolytic, } 20 \% \text { were beta haemolytic while as } 20 \% \text { were gamma } \\
\text { haemolytic. }\end{array}$} \\
\hline Keywords & \\
\hline $\begin{array}{l}\mathrm{M} \\
\mathrm{Pr} \\
\mathrm{Su}\end{array}$ & \\
\hline Article Info & \\
\hline $\begin{array}{l}\text { Accepted: } \\
26 \text { Septemb } \\
\text { Available } \\
10 \text { October }\end{array}$ & \\
\hline & \\
\hline
\end{tabular}

\section{Introduction}

Subclinical Mastitis is a common problem hindering the production growth in dairy farming. Dairy cattle are highly susceptible to mastitis because of increased metabolic stress to mammary gland (Radositits, et al., 2006). It has been found that despite implementation of recommended control measures for control of mastitis, the menace of mastitis still continues to haunt the dairy enterprise. Annual losses in the dairy industry due to mastitis have been approximately 2 billion dollars in USA and 526 million dollars in India due to subclinical (Varshney and Naresh, 2004).) According to Sheare and Harris (2003), subclinical mastitis is important due to the fact that it is 15 to 40 times more prevalent than the clinical form (for every clinical case of mastitis there will be 15-40 sub clinical cases), it usually precedes the clinical form, is of longer duration, difficult to detect, adversely affects milk quality and production and constitutes a reservoir of microorganisms that lead to infection of other animals within the herd (Khan et al., 2006).Unlike coagulase-positive Staphylococcus aureus, coagulase-negative staphylococci are of low virulence, and are rarely associated with clinical disease, although they frequently produce an 
inflammatory response measurable as an elevated somaticcell count in the milk (Kudinha et al., 2002). The study was conducted to determine the prevalence of subclinical mastitis along with the causative agent.

\section{Materials and Methods}

\section{Collection of milk samples}

The study was conducted at Mountain Livestock Research Institute (MLRI, Mansbal). A total of 100 lactating crossbred Jersy cows were selected for Californian Mastitis testing (CMT). The teats were cleaned with water, wiped dry with individual paper towels and disinfected with $70 \%$ ethyl alcohol on cotton. After discarding first few streaks of milk, milk was squirted from each teat in sterilised milk sampling tubes. The milk samples were transferred to laboratory at $5^{\circ} \mathrm{C}$ and processed for Somatic cell count (SCC) and culturing on the same day.

\section{Laboratory processing}

SCC was estimated by Direct microscopic method. A cell count of $>500000 / \mathrm{ml}$ was considered positive for subclinical mastitis.

For cultural isolation of the causative agent, a loop full of milk sample was inoculated in nutrient broth and kept for 24 hours at $37^{\circ} \mathrm{C}$ for development of turbidity. Next day a loop full of turbid nutrient broth was inoculated on Blood agar and kept for aerobic incubation at $37^{\circ} \mathrm{C}$ for $24 \mathrm{hrs}$. Isolate was not considered significant if less than 50 colonies grew from the sample of milk.

Identification of Staphylococcus spp., Streptococci spp., Escherichia coli, Diplococcus spp., Pseudomonas spp., Bacillus spp., Corynebacterium spp. and Micrococcus spp. was done on the basis of colony morphology on blood agar, type of haemolysis, Grams stain, Catalase test, oxidase test and coagulase testing. Coagulase testing was done using both slide and tube methods.

\section{Results and Discussion}

\section{Californian mastitis test}

At Mountain Livestock research institute, Mansbal, 100 cross bred Jersey cows were screened with Californian Mastitis test for presence of Subclinical mastitis. Out of 100 cows, 52 showed precipitation with or without gel formation. Thus prevalence of subclinical mastitis at Mansbal was 52\% as shown below:

Out of 400 quarters of 100 cows, 157 quarters were positive for subclinical mastitis on the basis of Californian Mastitis test. Hence the quarter prevalence was $39.25 \%$.

The selected samples were stained with modified Newman Lampert stain for somatic cell count (SCC). Out of all samples 49 samples showed somatic cell count of more than $500000 / \mathrm{ml}$ of milk and prevalence of subclinical mastitis on the basis of SCC was 49\% as shown below:

\section{Cultural identification}

The samples were cultured for bacteriological isolation of the causative agent. Out of all samples 45 samples showed positive growth of bacteria. Thus percent prevalence on the basis of cultural examination was $45 \%$. The main causative agent were staphylococcus as $42.2 \%$, Streptococcus was $11.1 \%$, Escherichia coli was $6.6 \%$, Diplococcus $2.2 \%$, Corynebacterium 2.2\%, Pseudomonas $2.2 \%$, mixed Staphylococcus and Streptococcus 22.2\%, Gram negative but not E.coli 4.4\%, Micrococcus $2.22 \%$ and Bacillus species was $4.44 \%$. 


\section{Californian mastitis test}

\begin{tabular}{|c|c|l|l|}
\hline CMT & No. of cows & & Infection \\
\hline N & 48 & No gel formation & Absent \\
\hline T & 32 & Slight precipitate & Infection risk by minor pathogen \\
\hline $1+$ & 14 & Precipitation but without gel & subclinical \\
\hline $2+$ & 5 & Gel formation & Serious subclinical \\
\hline $3+$ & 1 & Quick gel formation & $\begin{array}{l}\text { Subclinical mastitis near the } \\
\text { expression of clinical mastitis }\end{array}$ \\
\hline
\end{tabular}

\section{Somatic cell count}

\begin{tabular}{|l|c|c|}
\hline Somatic cell count $/ \mathrm{ml}$ & No. of samples & Disease \\
\hline$<500000$ & 51 & No \\
\hline$>500000$ & 49 & Yes \\
\hline
\end{tabular}

\section{Cultural identification}

\begin{tabular}{|l|c|c|c|}
\hline Major causative agent & Nos & $\begin{array}{c}\text { Average somatic cell } \\
\text { count }\end{array}$ & Per cent prevalence \\
\hline Staphylococcal & 19 & 2033333 & 42.2 \\
\hline Streptococcal & 5 & 1400000 & 11.1 \\
\hline E. coli & 3 & 1500000 & 6.6 \\
\hline Diplococcus & 1 & 1100000 & 2.2 \\
\hline Corynebacterium & 1 & 900000 & 2.2 \\
\hline Pseudomonas & 1 & 950000 & 2.2 \\
\hline $\begin{array}{l}\text { Mixed Staphylococcus and } \\
\text { Streptococcus }\end{array}$ & 10 & 1800000 & 22.2 \\
\hline Gram negative but not E.coli & 2 & 1100000 & 4.4 \\
\hline Micrococci & 1 & 800000 & 2.22 \\
\hline Bacillus & 2 & 900000 & 4.44 \\
\hline
\end{tabular}

Out of Staphylococcal, $73.68 \%$ were coagulase negative while as coagulase positive were $26.31 \%$. Out of streptococci, $60 \%$ were alpha haemolytic, $20 \%$ were beta haemolytic while as $20 \%$ were gamma haemolytic as shown below:

From the above results it is obvious that the dairy farm of Mountain Livestock Research Institute (MLRI, Mansbal) is having a presence of subclinical mastitis in cross bred jersey lactating cows with a prevalence of $52 \%$ and with a quarter prevalence of $39.25 \%$. These findings are in accordance with Bhat et al., 2016 who found an overall prevalence of subclinical mastitis in organised farms of Jammu to be 59.43 per cent $(\%)$ and quarter level prevalence to be at 34.78\%.Eriksson, 2013 has also reported that the prevalence of subclinical mastitis in Surveys from different developing countries have shown a SCM prevalence of $52.4-88.6 \%$ at cow level and $26.7-63.2 \%$ at quarter-level. But the findings of Akhoon et al., 2015are contrary who found prevalence of subclinical mastitis as $29.41 \%$ at Mansbal dairy farm. The reports of prevalence of sub clinical mastitis ranging from 29 per cent to 97 per cent have also been published different workers (Nickerson et al., 1995; Nath and Dutta, 2007; Junaidu et al., 2011 and Sharma et al., 2012). This variation could be due to difference in breeds, farm management, level of production and differences in study methods for studying mastitis employed by the investigators. (Bhat et al., 2016).

The major mastitides isolated were staphylococcus (42.2\%) of which coagulase negative staphylococcus were $73.68 \%$ and 
coagulase positive were $26.31 \%$. Our findings are in agreement with Bhat et al., 2016 who also found higher prevalence of staphylococcal subclinical mastitis to be $66.67 \%$. Coagulasenegative staphylococci are normal flora of healthy teat skin and constitute a constant source of bacteria to colonise the teat end. The results of the current study show that coagulasenegative staphylococci play a major role in causing bovine sub clinical mastitis and it agrees with Kudinha et al., 2002 who reported higher prevalence of Coagulase negative staphylococcal mastitis $(22.9 \%)$ than coagulase positive (17.1\%).Eriksson, 2013 also found that the most common udder pathogens were Coagulase Negative Staphylococci (CNS) in different areas of south Zambia.

\section{References}

Akhoon, Z. A., Gupta, S. K. 2015.Prevalence and diagnosis of sub clinical mastitis at cattle research station, Mansbal.The Northeast veterinarian, vol15(2), august.

Bhat, A. M., Soodan, J. S and Tikoo. 2016. A Study on Prevalence of Sub-Clinical Mastitis in Crossbred Dairy Cattle and itsPotential Risk FactorsJournal of Animal Research: v.6 n.4, p. 747-749. August 2016. doi: 10.5958/2277-940X.2016.00093.0.

Junaidu, A.U., Salihu, M.D., Tambuwala, F.M., Magaji, A.A.and Jaafaru, S. 2011. Prevalence of Mastitis in LactatingCows in some selected Commercial Dairy Farms in SokotoMetropolis. Adv. Appl. Sci. Res., 2(2): 290-294.

Khan, M. Z., and Khan, A. 2006. Basic facts of mastitis in dairy animals: A REVIEW.Pakistan Vet. J., 2006, 26(4): 204-208. 204.

Kudinhaa, T., and Simango, C.2002. Prevalence of coagulase-negative staphylococci in bovine mastitis in Zimbabwe.S.Afr.vet.Ver. (2002) 73(2): 62-65.

Lisa Eriksson. Prevalence of subclinical mastitis and udder pathogens in small holder dairy farms in Mapepe, Batoka and Choma areas in Zambia. Handledare: Karin Östensson, Institution enförklinis kavetenskaper Biträdandehandledare: YlvaPersson, Enhetenfördjurhälsaochantibiotikafrågor, SVA Examinator: Karin Persson Waller, InstitutionenförkliniskavetenskapersamtEnh etenfördjurhälsaochantibiotikafrågor, SVAExamensarbeteinomveterinärprogram met, Uppsala 2013.

Nath, A.K., and Dutta, J.B. 2007.Incidence of sub clinicalmastitis in dairy cows in and around Khanapara region.Indian. J. Vet. Med., 27(2): 117-118.

Nickerson, S.C., Owens, W.E and Boddie, R.L. 1995. Mastitisin Dry Heifers: Initial Studies on Prevalance and Control. J.Dairy. Sci., 78 (7): 1607-1618.

Radostits, O. M., Gay, C. C., Hinchkliff, K. W. and Constable, P.D. 2006. Veterinary Medicine, A text book of the diseases of cattle, horses, sheep, pigs and goats.9th edn. ELBS-BailliereTndal, London. pp. 673.

Sharma, A., Singh, R., Beigh, S.A. and Bhardwaj, R.K. 2012.Prevalence of sub-clinical mastitis in cross breed cattle fromJammu region.Vet. Pract., 13(2): 356-357.

Sheare, J. K., and B. Harris, Jr. 2003. Mastitis in dairy goats.Anim. Sci. Dept. Florida Coop. Ext. Serv. Inst. Food Agri. Sci; Univ. Fl. Gainesville, USA. pp: 1-6.

Varshney, J. P., and Naresh, R. 2004. Evaluation of homeopathic complex in the clinical management of udder diseases of riverine buffaloes.Homeopathy.93: 17.

\section{How to cite this article:}

Syed Ishfaq Ahmad Qadri, Muzaffar Shaheen, Shafayat ullah Baig, Hamidullah Malik, Zaffar Iqbal Bhat, Imtiyaz Ahmad Bhat, Pervaiz Ahmad Dar, Rather Waseem Yousuf, Raja Mohammed Iqbal, Adil Majid Bhat, Abrar ul Haq, Ifat Ashraf, Oveas Rafiq Parray, Fayaz Ahmad Shaikh, Bilal Ahmad Mir and Tasaduq Khaliq. 2017. Aetio-Prevalence Study on Bovine Sub Clinical Mastitis in Lactating Jersey Cross-Bred Cows. Int.J.Curr.Microbiol.App.Sci. 6(10): 3354-3357. doi: https://doi.org/10.20546/ijcmas.2017.610.392 